\begin{tabular}{|c|c|c|c|c|}
\hline $\begin{array}{c}\text { Jurnal Penelitian \& } \\
\text { PPM }\end{array}$ & ISSN: 2442-448X & Vol 4, No: 2 & Hal: $129-389$ & Juli 2017 \\
\hline
\end{tabular}

\title{
PERUBAHAN POLA PIKIR MASYARAKAT MENGENAI SAMPAH MELALUI PENGOLAHAN SAMPAH ORGANIK DAN NON ORGANIK DI DESA GENTENG, KECAMATAN SUKASARI, KAB. SUMEDANG
}

\author{
OLEH : \\ HETTY KRISNANI, SAHADI HUMAEDI, M. FEDRYANSYAH, DESSY HASANAH SITI ASIAH, GIGIN G. KAMIL \\ BASAR, SRI SULASTRI, NANDANG MULYANA,

\footnotetext{
1. Pusat Studi Kesejahteraan Anak dan Keluarga Fakultas Ilmu Sosial dan Ilmu Politik Universitas Padjadjaran

2. Pusat Studi Kewirausahaan Sosial, CSR dan Pengembangan Masyarakat Fakultas Ilmu Sosial dan Ilmu Politik Universitas Padjadjaran

3. Pusat Studi Kewirausahaan Sosial, CSR dan Pengembangan Masyarakat Fakultas Ilmu Sosial dan Ilmu Politik Universitas Padjadjaran

4. Pusat Studi Kesejahteraan Anak dan Keluarga Fakultas Ilmu Sosial dan Ilmu Politik Universitas Padjadjaran

5. Pusat Studi Kewirausahaan Sosial, CSR dan Pengembangan Masyarakat Fakultas Ilmu Sosial dan Ilmu Politik Universitas Padjadjaran

6. Pusat Studi Kesejahteraan Anak dan Keluarga Fakultas Ilmu Sosial dan Ilmu Politik Universitas Padjadjaran

7. Pusat Studi Kewirausahaan Sosial, CSR dan Pengembangan Masyarakat Fakultas Ilmu Sosial dan Ilmu Politik Universitas Padjadjaran
}

\begin{abstract}
ABSTRAK
Program Pengabdian Pada Masyarakat (PPM) ini dilatarbelakangi oleh pola pikir masyarakat yang masih menganggap bahwa sampah adalah sumber masalah, sehingga masyarakat umumnya menilai bahwa sampah adalah benda yang sudah tidak ada manfaatnya. Masyarakat belum terarah pada pemikiran bahwa sampah bila dikelola dan diolah dapat menjadi potensi yang menguntungkan bagi masyarakat itu sendiri. Kegiatan PPM di adakan di Desa Genteng, Kec. Sukasari, Kab. Sumedang yang memang masih memiliki masalah yang terkait dengan sampah tersebut. Desa Genteng merupakan salah satu desa yang memiliki potensi sumber daya alam yang melimpah, namun pengelolaan sumber daya alam tersebut seringkali menimbulkan dampak terhadap peningkatan jumlah sampah organic dan non-organik yang belum ditangani dengan tepat.

Dalam mengatasi masalah tersebut, tim bermaksud mengadakan kegiatan berupa pelatihan mengenai pengolahan sampah organik dan non organik yang dihasilkan dari pengelolaan sumber daya alam maupun sampah rumah tangga. Tujuan dari kegiatan ini adalah agar masyarakat sadar bahwa sampah bukan lagi sebuah masalah, namun justru sampah adalah potensi yang menguntungkan bilamana masyarakat memahami dan memiliki keterampilan dalam mengolah sampah tersebut. Kegiatan PPM ini akan berlangsung selama 7 bulan, dan dapat ditindaklanjuti dengan berbagai kegiatan yang mendukung hasil pelatihan pengolahan sampah tersebut.

Hasil dari kegiatan pelatihan tersebut, nampak bahwa warga lebih termotivasi untuk mulai memilah sampah organik dan non-organik dengan metode pengolahan dan pengelolaan yang bernilai ekonomis sebagai potensi usaha yang ramah lingkungan.
\end{abstract}

Kata Kunci : Sampah, Pemberdayaan Masyarakat, Manajemen Pengelolaan Sampah 


\begin{tabular}{|c|c|c|c|c|}
\hline $\begin{array}{c}\text { Jurnal Penelitian \& } \\
\text { PPM }\end{array}$ & ISSN: 2442-448X & Vol 4, No: 2 & Hal: $129-389$ & Juli 2017 \\
\hline
\end{tabular}

\begin{abstract}
The current Community-Based Project (Program Pengabdian Pada Masyarakat) is based on the thinking pattern of the local society that still think that rubbish is the major problem and thus it is already not valuable. The community has not been directed to the idea that if trash managed properly can benefit society itself. This program was held in Genteng Village, Sukasari Subdistrict, Sumedang Regency where the waste management is urgently needed. Genteng Village is one of the villages in Sumedang Regency that is rich in natural resources. However, the natural resources management leads to the increasing number of organic and non-organic waste product that have not been solved properly.

In solving the problem, this project aimed to held a program in the form of training of organic and non-organic waste processing management that mainly come from natural resources and household waste. The purpose of this activities is to make the community realized that garbage is no longer a problem, but in fact, the trash will largely benefit the society if could be managed properly through having skills in the management process of the trash. This program was being held during 7 months period, and can be followed up by various activities that support the results of this waste management training.

As the result from the training, it can be seen that the local community has been more motivated to begin allocating organic and non-organic rubbish properly through the method of waste processing management that economically and environmentally benefits the society itself.
\end{abstract}

Keywords $\quad$ : Garbage, Community Development, Waste Processing Management

\section{PENDAHULUAN}

\section{Latar Belakang}

Desa Genteng, Kecamatan Sukasari, Kabupaten Sumedang, merupakan daerah pegunungan dan perbukitan, termasuk dalam kategori dataran tinggi dengan ketinggian tempat 800-1200 mdpl. Salah satu masalah yang dimiliki oleh masyarakat di Desa Genteng adalah belum adanya pengelolaan sampah yang terpadu baik secara mandiri maupun terkoordinir oleh pihak pemerintah desa. Sementara sampah yang bersumber dari rumah tangga kian hari kian meningkat volumenya, tentunya hal ini akan menimbulkan berbagai permasalahan baru seperti wabah penyakit dan kerusakan atau menurunnya kualitas lingkungan masyarakat.

Masalah pencemaran lingkungan akibat minimnya pengelolaan sampah merupakan masalah yang pada beberapa wilayah belum teratasi dan menjadi beban serta permasalahan serius di hampir seluruh Pemerintah Kabupaten/Kota. Masalah tersebut muncul disebabkan karena sampah (khusunya sampah yang bersumber dari rumah tangga) tidak tertangani dengan baik. Rendahnya kesadaran masyarakat, keterbatasan lahan TPA, serta keterbatasan kemampuan pemerintah daerah dalam hal pembiayaan menjadi faktor pendukung yang mengakibatkan semakin kompleksnya masalah sampah tersebut. Kendala keterbatasan pendanaan dari pemerintah mengakibatkan harus dilakukannya upaya pencarian alternatif penanganan persampahan dengan tidak mengandalkan pendanaan dari Pemerintah. Melihat kondisi tersebut, penanganan sampah rumah tangga tidak dapat menjadi hanya tanggungjawab pemerintah saja, namun idealnya masalah penanganan sampah juga menjadi tanggungjawab masyarakat itu sendiri sebagai penghasil sampah. Karena pada dasarnya masyarakat mempunyai potensi besar dalam memberikan kontribusinya dalam hal pengolahan sampah.

Dengan memperhatikan kondisi tersebut, maka tim PPM berkesimpulan bahwa perlu adanya penanggulangan masalah tersebut, yang dimulai dari tingkatan rumah tangga, dengan mengadakan sebuah kegiatan Pengolahan Sampah Organik dan Non Organik Di Desa Genteng, Kecamatan Sukasari, Kab. Sumedang. Tujuannya adalah agar masyarakat (rumah tangga) setidaknya dapat mengelola dan mengolah sampah yang dihasilkan oleh masing-masing rumah tangga dapat dimanfaatkan oleh rumah tangga tersebut, dan pada akhirnya dapat meningkatkan kualitas lingkunga hidup mereka. 


\section{Kelompok Sasaran}

Kelompok sasaran dari kegiatan PPM ini adalah masyarakat di Desa Genteng, namun untuk mengawali kegiatan PPM ini hanya akan melibatkan para kader desa yaitu: Kader PKK, Kader Posyandu, Kader PLKB dan tokoh masyarakat dari kalangan ibu rumah tangga. Para kader inilah yang nantinya akan menjadi agen perubahan dalam lingkungan masyarakat.

\section{Perumusan Masalah}

Desa Genteng memiliki kekayaan sumber daya manusia dan alam yang melimpah. Desa Genteng merupakan salah satu desa dengan jumlah penduduk terbesar di Kecamatan Sukasari dengan kekayaan sumber daya alam berupa kopi dan tembakau yang menjadi komoditas bagi mata pencaharian petani kopi dan tembakau. Namun, jumlah penduduk yang besar dengan aktivitas dan mobilitas petani kopi yang tinggi dalam pengelolaan tanaman kopi dan tembakau memberikan dampak terhadap kelestarian lingkungan hidup di sekitarnya. Sampah rumah tangga dan produksi hasil pengelolaan kopi dan tembakau seringkali tidak ditangani dengan baik, akibatnya berdampak terhadap pencemaran air, tanah, dan udara yang seringkali menganggu kenyamanan warga sekitar sendiri.

Berdasarkan penelahaan data sekunder dan hasil observasi lapangan, Pengelolaan sampah rumah tangga masih dijalankan secara tradisional melalui pembakaran dan penimbunan di lahan kosong oleh karena tidak adanya TPA (Tempat Pembuangan Akhir) sampah dan TPS (Tempat Pembuangan Sampah). Di sekitar jalan raya jarang ditemukan adanya tempat sampah sehingga sampah seringkali masih berserakan di pinggir jalan terutama sampah hasil tani berupa ampas kopi. Salah satu permasalahan akan kesehatan lingkungan adalah stabilitas perairan sungai dan pemukiman warga oleh karena pencemaran tanah, udara, dan air oleh karena penimbunan sampah, terutama sampah hasil ampas kopi. Hal ini berdampak terhadap matinya ikan di kolam petani atau perairan yang memiliki tingkat keasaman yang buruk.

Merujuk pada kondisi tersebut, maka dinilai perlu dan penting untuk meningkatkan kemampuan masyarakat akan pengelolaan sampah organik dan non-organik yang baik sehingga akan mengurangi pencemaran tanah, air, dan udara, bahkan lebih jauh memberikan keuntungan terhadap masyarakat itu sendiri melalui pemberian pengetahuan dan keahlian untuk mengelola sampah yang bukan hanya ramah terhadap lingkungan namun juga bernilai ekonomis.

\section{Tujuan dan Manfaat}

\section{Tujuan}

Tujuan dari kegiatan Pengabdian kepada Masyarakat ini adalah :

1. Meningkatkan kapasitas masyarakat dalam pengelolaan sampah organik dan non-organik yang berasal dari sampah rumah tangga dan hasil industry pengolahan kopi.

2. Masyarakat termotivasi untuk mengelola sampah organik dan non-organik tersebut menjadi sampah yang ramah lingkungan dan bernilai ekonomis, sehingga diharapkan bukan hanya mengurangi dampak pencemaran lingkungan, melainkan membantu perekonomian masyarakat sekitar.

3. Masyarakat diharapkan dapat lebih produktif untuk menangani masalah yang ada di lingkungannya sebagai sebuah peluang ekonomis.

\section{Manfaat}

Masyarakat secara partisipatif terlibat dalam pengelolaan sampah organik dan non-organik ramah lingkungan dan bernilai ekonomis atas pengetahuan dan keterampilan yang dimilikinya usai pelatihan.

\section{TARGET KEGIATAN}

Kegiatan PPM ini ditujukan untuk memberikan solusi jangka pendek dalam penanganan perubahan pola pemikiran masyarakat terhadap pengelolaan sampah melalui kegiatan pelatihan Pengolahan Sampah Organik dan Non Organik Di Desa Genteng, Kecamatan Sukasari, Kab. Sumedang, sementara untuk jangka panjang dapat dilakukan atau tindak lanjut berupa kegiatan pendampingan untuk menguatkan hasil pelatihan tersebut. Dengan kegiatan PPM ini diharapkan masyarakat menyadari bahwa permasalahan sampah justru dapat berubah menjadi potensi, sehingga masyarakat termotivasi untuk mengolah sampah yang dihasilkan dari rumah tangga tersebut. 


\section{MATERI DAN METODE}

\section{Khalayak Sasaran}

Program Pengabdian Kepada Masyarakat (PKM) Prioritas ini tepat ditujukan kepada masyarakat Desa Genteng perihal keterkaitan dengan kondisi dan kebutuhan masyarakat Desa Genteng dan sesuai dengan Misi ke-5 Desa Genteng berdasarkan RPJM Desa Genteng 2016 tentang "Pelestarian Lingkungan Hidup". Dalam misi tersebut disebutkan bahwa terwujudnya pelestarian lingkungan hidup yang dapat berhasil guna dapat melalui penataan lingkungan baik yang terbentuk secara alamiah atau hasil penataan masyarakat.

Secara administratif Desa Genteng merupakan salah satu dari 7 Desa di Wilayah Kecamatan Sukasari Kabupaten Sumedang yang terletak $3 \mathrm{Km}$ ke arah Utara dari Kecamatan Sukasari. Desa Genteng berada di ketinggian 1200 diatas permukaan laut dengan wilayah \pm 1300 Hektar.

Desa Genteng memiliki potensi yang cukup besar, baik dari sumber daya manusia maupun sumber daya alam. Salah satu potensi dalam sumber daya alam yang terdapat di Desa Genteng adalah ketersediaan kopi dan tembakau. Namun, berdasarkan data RPJM Desa Genteng (2016), sampai saat ini potensi sumber daya belum benarbenar optimal diberdayakan. Beberapa hambatan yang dihadapi oleh masyarakat dalam pengelolaan sumber daya alam diantaranya adalah masih kurangnya penanam saham potensial yang berkenan untuk menanamkan modal investasinya di Desa Genteng serta masyarakat belum memiliki pengetahuan dan kecakapan khusus dalam pengelolaan sampah sisa pengolahan sumber daya alam sehingga berakibat pada pencemaran tanah, air, dan udara di Desa Genteng.

\section{Hasil Assessment dan Observasi Lapangan}

Desa Genteng memiliki potensi sumber daya alam dan manusia yang melimpah. Hal ini ditinjau dari ketersediaan dan potensi lahan serta potensi Desa Genteng sebagai salah satu desa dengan jumlah penduduk terbesar di Kecamatan Sukasari, Kabupaten Sumedang sehingga berdampak pada percepatan pembangunan desa bila dioptimalkan dengan tepat. Namun, pembangunan desa belum terlaksana secara optimal oleh karena beberapa hambatan yang disebabkan oleh keinginan masyarakat untuk bertahan pada pola aktivitas keseharian secara tradisional.

Berdasarkan RPJM Desa Genteng (2016), mayoritas Desa Genteng berpendidikan Sekolah Dasar (SD) dengan jumlah 921 orang. Hal ini menjadi sebuah perhatian bagi pemangku kepentingan pemerintahan desa yang mengkhawatirkan masa depan perekonomian, sosial, dan budaya masyarakat yang masih berpaku pada pekerjaan turun temurun sebagai petani selepas lulus sekolah dasar dengan anggapan bahwa pendidikan bukan hal yang menjadi penting. Hal ini bukan hanya berdampak pada mayoritas pekerjaan dan jumlah pengangguran pada masyarakat desa, namun juga berpengaruh terhadap pola pemikiran masyarakat desa terhadap pengelolaan potensi dan penanganan masalah yang terdapat pada sumber daya alam dan manusia di lingkungan fisik dan sosial di sekitarnya.

Salah satu masalah yang dihadapi dan belum tertangani oleh masyarakat diantaranya adalah sampah. Masyarakat Desa Genteng mengemukakan bahwa hingga saat ini belum ada TPA (Tempat Pembuangan Akhir) sampah yang menetap. Pemerintah lokal juga belum secara aktif berkoordinasi dengan Desa Genteng terkait dengan pembuangan dan pengelolaan sampah. Hal ini mengakibatkan masyarakat desa lebih memilih untuk membakar sampah rumah tangga di pekarangan rumah masing-masing, bahkan seringkali masih banyak yang tidak membakar dan memilih untuk membuang sampah di pinggir jalan raya desa. Hal ini berakibat bukan hanya pada pencemaran udara oleh karena bau sampah yang menumpuk, namun juga dapat berakibat pada matinya ekosistem air sekitar sawah oleh karena pencemaran air dan tanah akibat penumpukkan sampah. Selain itu, kebijakan pemerintah untuk memberdayakan masyarakat desa melalui pelatihan dan pengalokasian dana bagi terbentuknya Bank Sampah belum terlaksana di Desa Genteng oleh karena dananya terbagi oleh kepentingan penyediaan sarana prasarana desa yang lainnya. Selain itu, kesadaran masyarakat untuk mengelola sampahnya melalui Bank Sampah juga belum terlihat oleh karena masyarakat lebih terfokus untuk kegiatan perekonomian tanpa pemerhatian untuk pengelolaan dan pelestarian lingkungan.

Namun, dalam hal ini mayoritas masyarakat mengemukakan bahwa salah satu hal terkait sampah yang paling menganggu stabilitas lingkungan di Desa Genteng adalah ampas kopi 


\begin{tabular}{|c|c|c|c|c|}
\hline $\begin{array}{c}\text { Jurnal Penelitian \& } \\
\text { PPM }\end{array}$ & ISSN: 2442-448X & Vol 4, No: 2 & Hal: $129-389$ & Juli 2017 \\
\hline
\end{tabular}

sisa pengolahan hasil kopi di Desa Genteng. Dikemukakan bahwa saat ini mayoritas masyarakat Desa Genteng memiliki pekerjaan sebagai Petani Kopi. Hal ini dikarenakan ketertarikan masyarakat terhadap potensi ekonomi dengan profit yang lebih besar dibandingkan dengan bertani tanaman lainnya dan kesediaan pemerintah untuk menyediakan lahan dan bibit bagi petani kopi potensial di Desa Genteng. Proses pengolahan hasil kopi akan menghasilkan ampas kulit kopi yang seringkali hanya menjadi sampah dan tidak bisa dimanfaatkan kembali. Seringkali ampas kopi yang dihasilkan hanya dibuang di lahan-lahan kosong tertentu atau dibuang di sepanjang pinggir jalan raya. Adapun hasil dari sampah pengolahan hasil kopi diantaranya adalah limbah carian pengolahan kopi, ampas kopi, dan bungkus kopi sebagai sampah pasca pengolahan. Hal ini mengakibatkan adanya bau tidak sedap sepanjang jalan raya dan berdampak terhadap stabilitas perairan perikanan yang menyebabkan matinya ikan di perairan sawah. Hal ini dapat merugikan petani sawah dan peternak ikan yang mengalami pencemaran pada perairan di kolam ikannya. Namun, hingga saat ini belum adanya tindak lanjut terhadap pengelolaan sampah dari pengelolaan hasil panen kopi walaupun dampak negatif telah dirasakan oleh mayoritas warga masyarakat. Hal yang menjadi penghambat utama dalam pengelolaan sampah hasil kopi diantaranya adalah belum adanya kesadaran, pengetahuan, dan kecapakan khusus masyarakat khususnya petani kopi dan tengkulak untuk memanfaatkan kembali sampah dari hasil pengelolaan kopi sesuai dengan misi desa dalam pelestarian lingkungan hidup. Masyarakat belum memiliki kesadaran untuk memelihara dan melestarikan lingkungan atas dampak dari pencemaran dari sampah organik dan non-organik pengelolaan hasil kopi dan belum tersampaikannya pengetahuan dan kecapakan bagi petani dan tengkulak untuk memanfaatkan sampah hasil kopi tersebut.

\section{Analisa Kebutuhan Berdasarkan Hasil Assessment Lapangan}

Berdasarkan hasil assessment lapangan mengenai kondisi masyarakat akan ketersediaan kegiatan pelestarian lingkungan hidup, maka dapat ditinjau bahwa masyarakat belum memiliki kesadaran akan pentingnya pelestarian lingkungan hidup atas dasar hasil dari kegiatan perekonomian masyarakat sehingga memungkinkan terjadinya kesinambungan antara kegiatan perekonomian masyarakat dengan pelestarian lingkungan hidup.
Dalam hal ini, maka potensi untuk pengendalian stabilitas lingkungan hidup dapat ditelaah dari keadaan mayoritas mata pencaharian warga yang didominasi oleh Petani Kopi. Maka, pengelolaan sampah dari hasil pengolahan kopi dapat ditinjau dari limbah cair dan padat ampas kopi serta sampah non-organik dari hasil pasca pengolahan kopi. Dalam hal ini, kesadaran masyarakat dapat ditingkatkan dengan sosialisasi kepada masyarakat akan dampak negatif dari sampah yang dihasilkan serta bagaimana sampah tersebut dapat menghasilkan dampak positif akan potensi perekonomian baru bagi masyarakat bila dikelola dengan baik.

Bila ditinjau lebih lanjut, masyarakat belum memiliki TPS (Tempat Pembuangan Sampah) dan TPA (Tempat Pembuangan Akhir) yang akan berdampak terhadap tertatanya pengelolaan sampah organik dan non-organik di lingkungan fisik sekitar Desa Genteng. Namun, hal ini dapat diatasi dengan pembinaan masyarakat untuk mengetahui manfaat Bank Sampah sebagaimana yang telah dicanangkan oleh pemerintah bagi desa. Sosialisasi akan manfaat dan dampak positif dari adanya Bank Sampah dapat menjadi salah satu solusi alternative bagi masyarakat untuk mengelola sampah sebagai pengganti dari metode pembakaran bagi sampah di pekarangan rumah yang akan berdampak pada pencemaran udara. Ketersediaan Bank Sampah dapat menjadi salah satu alternatif bagi warga untuk mengelola sampah hasil pengolahan kopi dan rumah tangga secara terpusat dan bermanfaat bagi pergerakan sosial ekonomi masyarakat Desa Genteng. Sebagai contoh, hal ini dapat dijalankan atas kerjasama dengan koperasi, ibu-ibu PKK, atau komunitas pemuda dalam karang taruna desa.

Berdasarkan penelaahan hasil assessment lapangan, maka dapat ditinjau bahwa perlu diadakannya program pengabdian kepada masyarakat melalui kegiatan pelatihan Perubahan Pola Pikir Masyarakat Mengenai Sampah Melalui Pengolahan Sampah Organik dan Non-Organik di Desa Genteng, Kecamatan Sukasari, Kabupaten Sumedang.

\section{Metode Pelaksanaan PKM}

Metode yang digunakan dalam kegiatan PPM adalah dengan melakukan kegiatan pelatihan yang diawali terlebih dahulu dengan pemberian materi, kemudian diskusi, dan praktik atau simulasi. Kegiatan pelatihan dipandu oleh narasumber (tenaga ahli) sebagai fasilitator pelatihan dan 
dibantu dengan seperangkat alat untuk melakukan simulasi atau praktik secara langsung. Adapun tahapan dalam kegiatan PKM diantaranya adalah persiapan kegiatan PPM, Pemetaan Wilayah, Pelaksanaan Pelatihan, dan Monitoring dan Evaluasi.

\section{Indikator Keberhasilan Kegiatan}

Setiap kegiatan tentunya harus memiliki tujuan dan manfaat, demikian juga dalam kegiatan PPM ini memiliki tujuan dan manfaat yang perlu untuk diwujudkan melalui tahapan dan proses yang sistematis dan terukur. Adapun indikator-indikator keberhasilan kegiatan dalam PPM ini diantaranya adalah Mitra mengetahui dan memahami tentang pengolahan sampah organik dan non organik, Mitra sudah terampil dalam mengolah sampah organik dan non organik menjadi barang yang bermanfaat, Mitra lebih termotivasi untuk mengelola serta mengolah sampah yang bersumber dari rumah tangga, Tim berhasil menulis artikel dan dipublikasikan pada jurnal, yaitu Jurnal Share.

\section{HASIL DAN PEMBAHASAN}

\section{Kegiatan Assessment}

Bila ditinjau berdasarkan sumber daya potensial yang terdapat di Desa Genteng, maka berdasarkan hasil observasi lapangan dan penelaahan data sekunder, diketahui dalam pemetaan sosial berikut ini. Berdasarkan penelaahan data sekunder desa dan observasi lapangan, maka diketahui bahwa sebagian besar lahan di Desa Genteng digunakan untuk lahan pemukiman dan pertanian. Mayoritas penduduk menggunakan lahan pertanian untuk penanaman kopi dan tembakau. Dalam hal transportasi, maka mayoritas masyarakat Desa Genteng menggunakan transportasi publik seperti halnya Angkutan Umum dan Ojeg. Salah satu angkutan umum akan melewati Desa Genteng menuju pasar tradisional di Tanjungsari. Hal ini memudahkan bagi masyarakat desa untuk menempuh perjalanan bila tidak ada kendaraan pribadi. Masyarakat juga seringkali menggunakan motor bila jarak tempuh jauh dan memerlukan waktu yang cepat. Dalam hal ini, kondisi jalan raya di Desa Genteng masih berbatu dan terbilang rawan untuk kendaraan karena kondisi jalan yang curam dan banyak jalan berlubang. Jalan sekitar pemukiman masih belum beraspal dan masih berlandaskan tanah.
Berdasarkan informasi yang diperoleh dari mayoritas warga yang bekerja sebagai petani kopi, maka diketahui bahwa rata-rata penghasilan petani kopi tidak lebih dari Rp 2.500.000/bulan. Hal ini didasarkan atas dasar penghasilan rata-rata petani kopi bila hasil panen maksimal yaitu Rp 21.000.000 per tahun. Adapun pola pemukiman warga dibagi atas dasar pemetaan batas wilayah dusun dan memanjang di sepanjang jalan.

Dalam hal pendidikan, masyarakat Desa Genteng rata-rata berpendidikan SD (Sekolah Dasar) dengan jumlah 921 orang. Namun, hal ini terbilang berkembang setelah dibukanya SMP Terbuka bagi masyarakat dengan pendidikan akhir SD. Sarana prasarana pendukung pendidikan di Desa Genteng belum memadai. Kondisi infrastruktur pendukung ketersediaan pelayanan pendidikan masih perlu diperbaharui. Ketersediaan sekolah sudah memberikan aksesibilitas yang mudah bagi masyarakat untuk menempuh pendidikan di desa. Namun, jarak tempuh yang jauh seringkali memberikan beban kepada anggota masyarakat dengan perekonomian rendah untuk menyekolahkan anaknya. Hal ini juga didukung oleh tradisi pola pemikiran masyarakat yang masih menganggap bahwa pendidikan hanya cukup sampai sekolah dasar, setelah itu anak dapat meneruskan usaha orangtuanya untuk menjadi petani karena dinilai penghasilan petani sudah mencukupi kebutuhan keluarga. Dalam hal ini, penduduk laki-laki lebih banyak yang memiliki pendidikan lebih tinggi dibandingkan dengan penduduk perempuan. Pola pemikiran masyarakat yang masih terfokus pada penerusan usaha orangtua untuk bertani sehingga kesadaran untuk bersekolah hingga jenjang yang lebih tinggi masih belum mumpuni. Kesadaran akan pentingnya pendidikan bagi perkembangan pertanian warga juga belum tersosialisasikan dengan baik.

Dalam hal kelembagaan, beberapa anggota masyarakat sudah berinisiasi untuk mendirikan koperasi. Namun, koperasi ini belum berjalan dan warga lebih memilih untuk meminjam uang kepada pendonor swasta dibandingkan dengan ketersediaan koperasi. Kelompok tani kopi, kelompok tani tembakau, kelompok pengrajin bambu tersedia di Desa Genteng. Masing-masing kelompok memiliki perwakilan di setiap dusun dan belum terfokus pada persatuan untuk pembangunan sosial ekonomi anggotanya. Komunitas pengrajin bambu telah menghasilkan produk industri rumah tangga dari bambu. Namun hal ini belum mendukung perkembangan masyarakat untuk mengarah kepada industry kreatif. Adapun petani tembakau belum memiliki 
pengelolaan hasil produk, sedangkan petani kopi sedang merintis pengelolaan produk hasil kopi untuk dipasarkan dalam bentuk jadi.

Pengelolaan sampah rumah tangga masih dijalankan secara tradisional melalui pembakaran dan penimbunan di lahan kosong oleh karena tidak adanya TPA (Tempat Pembuangan Akhir) sampah dan TPS (Tempat Pembuangan Sampah). Di sekitar jalan raya jarang ditemukan adanya tempat sampah sehingga sampah seringkali masih berserakan di pinggir jalan terutama sampah hasil tani berupa ampas kopi. Salah satu permasalahan akan kesehatan lingkungn adalah stabilitas perairan sungai dan pemukiman warga oleh karena pencemaran tanah, udara, dan air oleh karena penimbunan sampah, terutama sampah hasil ampas kopi. Hal ini berdampak terhadap matinya ikan di kolam petani atau perairan yang memiliki tingkat keasaman yang buruk.

Interaksi sosial masyarakat terlihat sangat baik bila ditinjau dari masih adanya sifat kegotongroyongan masyarakat dalam berbagai kegiatan. Misalnya saja dalam kegiatan kerja bakti sosial, kegiatan pembangunan baik yang dilaksanakan oleh perorangan ataupun kegiatan yang berkaitan dengan program pemerintah. Baik yang dilaksanakan oleh pemerintah desa ataupun kegiatan-kegiatan yang dilaksanakan melalui program lainnya. Seperti halnya gotong-royong dalam kegiatan pembangunan desa atas kerjasama dengan pemerintah desa, kebersihan lingkungan, membangun sarana umum dan sarana keagamaan, membantu warga yang tertimpa musibah (kematian), kawinan, membuat hunian, dII)

Desa Genteng memiliki potensi yang cukup besar, baik dari sumber daya manusia maupun sumber daya alam. Salah satu potensi dalam sumber daya alam yang terdapat di Desa Genteng adalah ketersediaan kopi dan tembakau. Namun, berdasarkan data RPJM Desa Genteng (2016), sampai saat ini potensi sumber daya belum benarbenar optimal diberdayakan. Beberapa hambatan yang dihadapi oleh masyarakat dalam pengelolaan sumber daya alam diantaranya adalah masih kurangnya penanam saham potensial yang berkenan untuk menanamkan modal investasinya di Desa Genteng serta masyarakat belum memiliki pengetahuan dan kecakapan khusus dalam pengelolaan sampah sisa pengolahan sumber daya alam sehingga berakibat pada pencemaran tanah, air, dan udara di Desa Genteng.

Program Pengabdian Kepada Masyarakat (PKM) Prioritas ini tepat ditujukan kepada masyarakat Desa Genteng perihal keterkaitan dengan kondisi dan kebutuhan masyarakat Desa Genteng dan sesuai dengan Misi ke-5 Desa Genteng berdasarkan RPJM Desa Genteng 2016 tentang "Pelestarian Lingkungan Hidup". Dalam misi tersebut disebutkan bahwa terwujudnya pelestarian lingkungan hidup yang dapat berhasil guna dapat melalui penataan lingkungan baik yang terbentuk secara alamiah atau hasil penataan masyarakat.

\section{Kegiatan Pelatihan}

Tahapan berikutnya adalah kegiatan pelatihan, kegiatan pelatihan ini berjudul: Perubahan Pola Pikir Masyarakat Mengenai Sampai Melalui Pengolahan Sampah Organik dan Non Organik. Sesuai dengan tujuan awal, seluruh kegiatan PKM ini dimaksudkan untuk:

1. Meningkatkan kapasitas masyarakat dalam pengelolaan sampah organik dan non-organik yang berasal dari sampah rumah tangga dan hasil industry pengolahan kopi.

2. Masyarakat termotivasi untuk mengelola sampah organik dan non-organik tersebut menjadi sampah yang ramah lingkungan dan bernilai ekonomis, sehingga diharapkan bukan hanya mengurangi dampak pencemaran lingkungan, melainkan membantu perekonomian masyarakat sekitar.

3. Masyarakat diharapkan dapat lebih produktif untuk menangani masalah yang ada di lingkungannya sebagai sebuah peluang ekonomis.

Pelatihan ini didampingi oleh pemateri pengelolaan sampah dari Komunitas "My Darling" (Masyarakat Sadar Lingkungan) Kota Bandung. Kegiatan pelatihan ini menguraikan mengenai jenis-jenis sampah dan cara pemilahaannya, dampak negatif dari pengelolaan sampah yang tidak tepat terhadap pencemaran air, tanah, dan udara, dan pengelolaan sampah organik dan nonorganik bernilai ekonomis yang ramah lingkungan. Kegiatan pelatihan ini dihadiri oleh 35 orang masyarakat lokal yang terdiri dari pejabat pemerintahan desa setempat (Staf Kelurahan/RT/RW), ibu-ibu rumah tangga, petani kopi, maupun pemuda setempat. Peserta berpartisipasi aktif dalam kegiatan dengan menjalani setiap tahapan kegiatan dengan baik dan antusias ditinjau dari banyaknya peserta yang terlibat dalam kegiatan praktik dan tanya jawab. Penyampaian materi oleh fasilitator dinilai tepat 
oleh karena pemilahan dan pengelolaan sampah yang disampaikan sesuai dengan kebutuhan dan kondisi lingkungan dimana peserta tinggal. Perlengkapan yang digunakan oleh fasilitator dalam mengolah sampah juga mudah untuk ditemui oleh peserta, sehingga peserta termotivasi untuk menerapkan pengetahuan dan keahlian yang baru saja dimilikinya ke lingkungan rumahnya masing-masing.

Berdasarkan hasil pre-test dan post-test, maka dapat ditinjau bahwa peserta mengalami perubahan yang positif dengan meningkatkan pengetahuan akan dampak negatif pengelolaan sampah yang kurang tepat, tata cara memilah sampah organik dan non-organik, dan pengelolaan sampah yang bernilai ekonomis namun ramah lingkungan. Sebagian besar peserta pelatihan juga mengemukakan bahwa pelatihan mengenai pengelolaan sampah ini baru pertama kali diadakan di desanya dan dinilai sangat tepat karena permasalahan sampah di Desa Genteng sudah dinilai membahayakan bagi keberlangsungan ketersediaan air bersih. Di akhir acara pelatihan, masing-masing peserta berhasil membuat sebuah hasil produk kreasi berupa gantungan kunci dari sampah non-organik yang telah diolah untuk menjadi barang siap jual.

\section{Rencana Keberlanjutan Program}

Merujuk pada hasil-hasil kegiatan PPM yang telah dilakukan, terutama kegiatan pelatihan mengenai pengolahan sampah organik dan nonorganik, maka nampakya diperlukan kegiatan pendampingan bagi keberlanjutan pengelolaan sampah bernilai ekonomis. Pendampingan dilakukan guna meningkatkan kreativitas pengelolaan sampah baik dalam jenis produksi maupun kemasan/hasil dari produksi tersebut dan pemasaran atas hasil produk, dengan memanfaatkan potensi lingkungan sosial setempat sehingga diupayakan dapat berlangsung lama dengan upaya pemberdayaan masyarakat sendiri. Kegiatan ini dapat dijalankan dengan kegiatan penguatan kelompok usaha yang diadakan atas dasar pelatihan koperasi desa, guna terjalinnya kerjasama kelembagaan pemerintah dengan masyarakat setempat.

\section{KESIMPULAN DAN SARAN}

\section{Kesimpulan}

Berdasarkan hasil pemetaan atau
assessment yang telah dilakukan, potensi pengelolaan limbah hasil pengolahan sumber daya alam bukan hanya dapat mengembangkan pola pemikiran masyarakat akan pelestarian lingkungan hidup, namun juga berpengaruh terhadap kemajuan sosial ekonomi masyarakat Desa Genteng. Sebagaimana diketahui bahwa bila limbah sisa pengolahan sumber daya alam telah dikelola dengan baik oleh masyarakat, maka hal ini bukan hanya memberikan keleluasan masyarakat Desa Genteng untuk beraktivitas tanpa adanya pencemaran air, udara, dan tanah yang berlebihan oleh karena limbah hasil pengolahan sumber daya alam yang menjadi komoditi dari mata pencaharian sebagian besar masyarakat, namun juga dapat dimanfaatkan untuk menjadi barang yang lebih bermanfaat seperti halnya pengelolaan limbah ampas kopi untuk menjadi pupuk atau pakan ternak.

Pengelolaan limbah sumber daya alam bagi masyarakat Desa Genteng juga selaras dengan misi Desa Genteng yang tengah difokuskan oleh pemerintah desa yaitu untuk pelestarian lingkungan hidup Desa Genteng. Selain itu, hal ini juga dapat menjadi salah satu media bagi masyarakat Desa Genteng untuk lebih produktif dan proaktif terhadap pengelolaan sumber daya alam sebagai salah satu potensi besar bagi masyarakat Desa Genteng. Lebih jauh, diharapkan dengan adanya pelestarian lingkungan hidup, hal ini juga akan selaras mendukung upaya masyarakat Desa Genteng untuk turut berkontribusi terhadap pemeliharaan tanah, air, dan udara yang menjadi sumber daya alam utama yang dapat diperbaharui sehingga berdampak terhadap stabilitas hasil panen masyarakat.

\section{Saran}

Pengabdian pada masyarakat yang akan dilaksanakan ini bertujuan untuk mengembangkan pola pemikiran masyarakat akan pengelolaan sampah organik dan non-organik dari hasil pengelolaan sumber daya alam di lingkungan fisik sekitarnya. Namun, hal ini ditinjau dapat semakin berkembang bila didukung atas kerjasama dengan pemerintah desa dan kabupaten guna peninjauan kembali sarana prasarana pendukung untuk pengelolaan sampah yang baik, seperti halnya diadakan TPA (Tempat Pembuangan Akhir) dan TPS (Tempat Pembuangan Sampah) karena hal ini juga akan berdampak terhadap peningkatan pola perilaku masyarakat agar lebih disiplin dalam membuang sampah di lingkungan fisik di sekitarnya yang diharapkan dapat mengurangi 


\begin{tabular}{|c|c|c|c|c|}
\hline $\begin{array}{c}\text { Jurnal Penelitian \& } \\
\text { PPM }\end{array}$ & ISSN: 2442-448X & Vol 4, No: 2 & Hal: $129-389$ & Juli 2017 \\
\hline
\end{tabular}

pencemaran air, tanah, dan udara di Desa Genteng.

Selain itu, pendampingan pengelolaan sampah oleh masyarakat sekitar juga sebaiknya ditinjau secara langsung oleh pemerintah lokal setempat guna diadakan pendampingan lebih lanjut seperti misalnya diadakan penguatan kelompok usaha pengelolaan sampah bernilai ekonomis yang ramah lingkungan. Penguatan kelompok usaha dapat memanfaatkan keberadaan koperasi desa yang sudah lama tidak dijalankan sehingga terjalin koordinasi yang sinergi antara pemerintah dengan masyarakat lokal setempat.

\section{DAFTAR PUSTAKA}

Adi. Isbandi Rukminto. 2008. Intervensi Komunitas Pengembangan Masyarakat Sebagai Upaya Pemberdayaan Masyarakat. Jakarta: Rajawali Pers

Cary, Lee. 1970. Community Development As A Process. Missouri. Univerity of Missouri Press.

Hikmat, Harry. 2006. Strategi Pemberdayaan Masyarakat. Bandung : Humaniora Utama Press.

Ife, Jim. 2008. Community Development : Alternatif Pengembangan Masyarakat di Era Globalisasi. Jogjakarta. Pustaka Pelajar.
Kartasasmita, Ginandjar. 1996. Pembangunan untuk rakyat: memadukan pertumbuhan dan pemerataan. Jakarta. CIDES

Lewis, Judith A., 1991, Management of Human Services Programs. California Brooks/Cole Publishing Company

Parsons, Ruth J., James D. Jorgensen, Santos H. Hernandez, 1994. The Integration of Social Work Practice. Wadsworth, Inc., California

Raharjo, ST. 2015. Assessment untuk Praktik Pekerjaan Sosial dan Kesejahteraan Sosial. Bandung: Unpad Press

2015. Dasar Pengetahuan Pekerjaan Sosial. Bandung: Unpad Press.

2015. Keterampilan Pekerjaan Sosial: Dasar-dasar. Bandung, Unpad Press.

Rappaport, J., 1984. Studies in Empowerment: Introduction to the Issue, Prevention In Human Issue. USA.

Rencana Pembangunan Jangka Menengah Desa 2011-2015. Desa Genteng, Kecamatan Sukasari, Kabupaten Sumedang. 2011.

Suharto. Edi.1997.Pembangunan, Kebijakan Sosial, dan Pekerjaan Sosial. Bandung: LSP-STKS

Wibhawa. Budhi, dkk, 2010.Dasar-Dasar Pekerjaan Sosial. Widya Padjadjaran: Bandung 